\title{
Landslides
}

\section{Patterns of movement in the Ventnor landslide complex, Isle of Wight, southern England \\ --Manuscript Draft--}

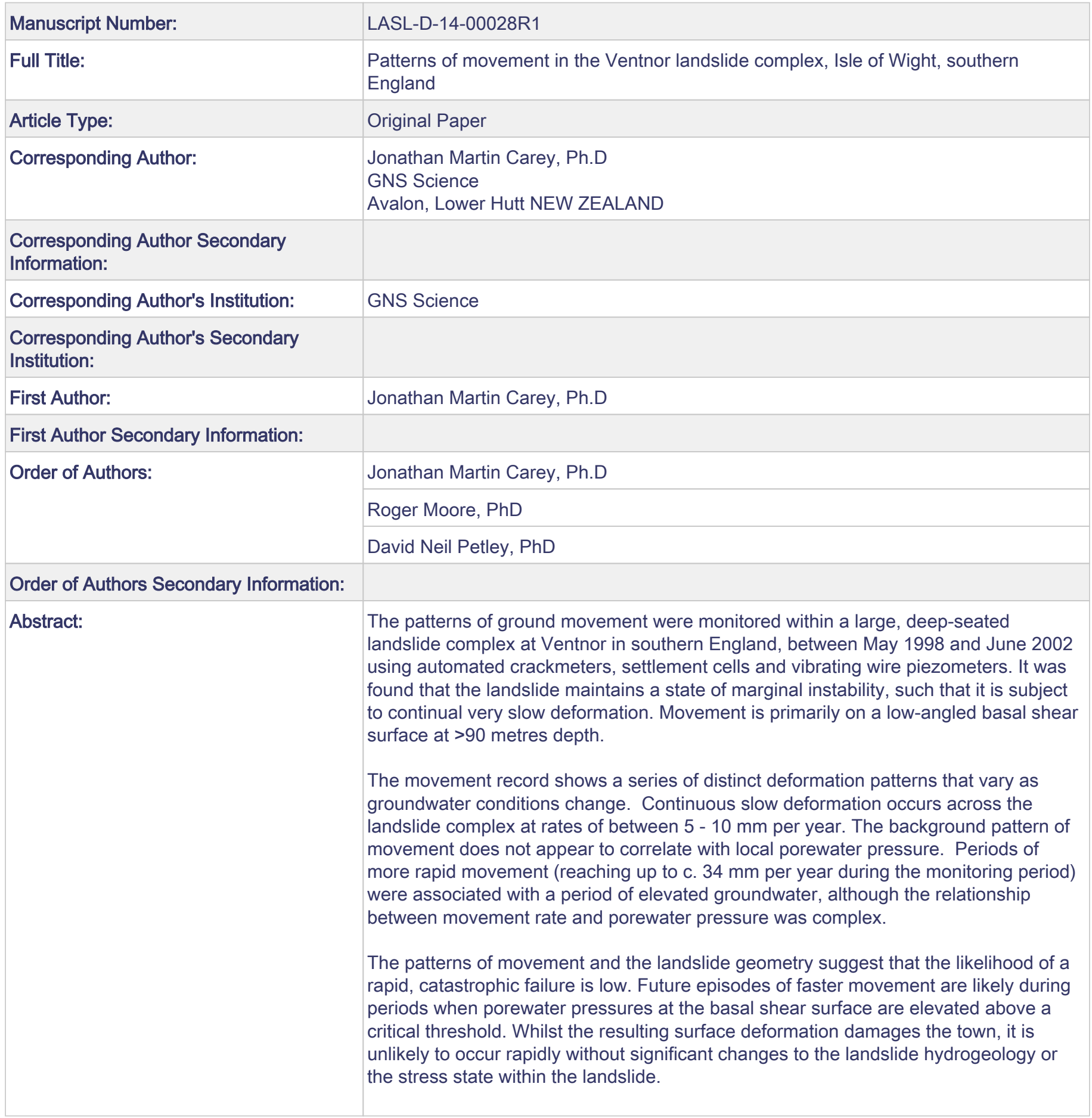


Patterns of movement in the Ventnor landslide complex, Isle of Wight, southern England

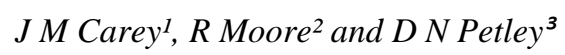

${ }^{1}$ GNS Science, 1 Fairway Drive, Avalon, Lower Hutt 5010, PO Box 30368, New Zealand

${ }^{2}$ Department of Geography, University of Sussex, Falmer, Brighton, BN1 9RH, UK and

CH2M HILL, Lyndon House, 62 Hagley Road, Edgbaston, Birmingham, B16 8PE, UK

${ }^{3}$ School of Environmental Sciences, University of East Anglia, Norwich, NR4 7TJ, UK; formerly of:

Department of Geography, Durham University, Durham, DH1 3LE, UK.

\begin{abstract}
The patterns of ground movement were monitored within a large, deep-seated landslide complex at Ventnor in southern England, between May 1998 and June 2002 using automated crackmeters, settlement cells and vibrating wire piezometers. It was found that the landslide maintains a state of marginal instability, such that it is subject to continual very slow deformation. Movement is primarily on a low-angled basal shear surface at $>90$ metres depth.
\end{abstract}

The movement record shows a series of distinct deformation patterns that vary as groundwater conditions change. Continuous slow deformation occurs across the landslide complex at rates of between $5-10 \mathrm{~mm}$ per year. The background pattern of movement does not appear to correlate with local porewater pressure. Periods of more rapid movement (reaching up to c. $34 \mathrm{~mm}$ per year during the monitoring period) were associated with a period of elevated groundwater, although the relationship between movement rate and porewater pressure was complex.

The patterns of movement and the landslide geometry suggest that the likelihood of a rapid, catastrophic failure is low. Future episodes of faster movement are likely during periods when porewater pressures at the basal shear surface are elevated above a critical threshold. Whilst the resulting surface deformation damages the town, it is unlikely to occur rapidly without significant changes to the landslide hydrogeology or the stress state within the landslide.

\title{
1. INTRODUCTION
}

In recent years, a key area of landslide research has been behaviour forecasting and, in some cases, behaviour prediction, based upon a better understanding of mass-movement mechanisms and processes (e.g. Corminas et al. 2009; Du et al. 2013). In principle, such approaches provide powerful tools in managing landslide risk, and there have been notable successes in which failure prediction has increased safety, especially in high-wall open-pit mines (e.g. Pankow et al. 2013). Advances have been made in the analysis of remotely-sensed imagery, such as high resolution satellite technology (e.g. Quickbird and Ikonos images) and satellite radar interferometry (INSAR), which have improved landslide-monitoring capability (Yin et al. 2010; Petley, 2012). Whilst these tools allow the generation of high resolution displacement datasets with high spatial resolution (Casagli et al., 2010 for example), there are few studies concentrating on the development of techniques to analyze the movement patterns. Such studies have shown potential, in some instances, to be developed into forecasting methodologies (e.g. Saito, 1965, 1980; Fukuzono, 1990; Petley et al., 2002; Massey et al., 2013), but beyond high-wall mining, reliable behaviour forecasting and failure prediction will only be possible if 
the underlying controls on observed movement patterns are understood. Thus, there is a need for more level and the properties of the failing materials.

This paper examines spatial and temporal patterns of movement in a deep-seated landslide complex at Ventnor in southern England (Fig 1), which is subject to long-term, slow ground movement. It analyses the results of a high-resolution landslide monitoring dataset collected between 1998 and 2002 in order to better understand the nature of movements in such a deep-seated landslide, and the controls of that movement. The Ventnor landslide (Figs 1c and 2) underlies the town of Ventnor with a population of about 6000 people; it has houses, schools, shops, roads and other infrastructure on and around it. Although displacement rates are slow, movement has caused significant damage to property and infrastructure. The landslide has been subject to measures to manage the hazard for a long time; the cost of these measures was estimated to exceed $£ 3$ million per annum a decade ago (McInnes, 2000). Behavior forecasting and prediction, for this landslide, is critically important with regards to evaluation life safety, economic damage and the assessment of the benefits of possible future mitigation strategies.

\section{THE VENTNOR LANDSLIDE}

The coastal area of the Isle of Wight known locally as 'The Undercliff' is one of the largest landslide complexes in the British Isles (Fig 1c). A review of landsliding in the UK (Geomorphological Services Ltd 1987) identified The Undercliff as the largest urban area affected by landsliding in Britain, and it has been the subject of investigation for a several decades (e.g. Chandler, 1984; Hutchinson et al., 1991a, 1991b; Lee and Moore, 1991; Moore et al., 1995; Hutchinson and Bromhead, 2002; Moore et al., 2007a, 2007b). Whilst the actual date of the original Undercliff landslides remain unknown (Moore et al., 2007b) an outline of its late Quaternary history is provided in a number of previous studies (Hutchinson, 1987; Lee and Moore 1991). These studies have postulated that the landslide system is likely to have initiated south of the present shoreline on the dip slope on the Upper and Lower Cretaceous strata which extends to St Catherine's deep approximately $2.8 \mathrm{Km}$ offshore (Hutchinson and Bromhead, 2002). These studies suggest that the coastal landslides along the Undercliff would have been in place during the Late-glacial Interstadial, around 11300 - 12100 years BP.

The Ventnor landslide, a sub-component of The Undercliff, is located on the south coast of the Isle of Wight, just off the southern coast of England (Fig 1) at $50.594441^{\circ}$ Lat, $-1.211538^{\circ}$ Long. It has a total onshore area of $0.7 \mathrm{~km}^{2}$ of unstable ground (Fig 2): the length from crown to toe is $1,045 \mathrm{~m}$ and the maximum width is $563 \mathrm{~m}$, spanning an elevation range of approximately $135 \mathrm{~m}$ from the crown to the current shoreline before extending offshore below sea level.

Moore et al., (2007b) proposed an evolutionary model to account for the formation of the Ventor landslide system from the Holocene to the current day. The model assumes that at around 13,000 years BP the landslide toe lay seaward of its current location having migrated north of its initiation point at $\mathrm{St}$ Catherine's Deep (Hutchinson, 2002). The model suggests that further retrogression of the landslide 
complex would have occurred in response to rising sea levels and periods when groundwater levels landslide is most likely to have occurred as a series of multiple rotational block failures. This process has continued landward to its current position. The most recent landslide activity has occurred in upper Ventnor over the last 100 years and has manifest in the development of the Lowtherville graben (Fig 2).

Whilst a number of uncertainties remain the evolutionary model indicates that present day landslide movement is most likely triggered by rainfall and groundwater fluctuations rather than coastal or offshore processes which have been significantly reduced by the construction of cliff protection measures.

Detailed geomorphological mapping (Lee and Moore, 1991) and structural-damage surveys of the buildings have informed two ground investigations at Ventnor (Halcrow, 2006) which were funded by the Isle of Wight Council. Included in the ground investigations were five deep rotary and open-cored boreholes, accompanied by engineering and geophysical logging of materials; laboratory-based testing of samples; and installation of subsurface inclinometers and standpipe piezometers (Fig 2).

\subsection{GEOMORPHOLOGY AND DAMAGE RECORDS}

The key geomorphological features of the Ventnor landslide complex (Fig 3) comprise:

- $\quad$ The Chalk Downs (A) (a low altitude upland area), located landward to the north of the main landslide complex. The area is largely unaffected by instability but is an important source of groundwater for the landslide;

- $\quad$ The Lowtherville Graben (B), a $450 \mathrm{~m}$ by $20 \mathrm{~m}$ depression formed from Upper Greensand and Chalk, located at the upslope margin of the upper tier landslide units. This feature is sharply defined by two parallel tension scarps that are subject to ongoing differential horizontal and vertical movement, such that the graben continues to develop. The graben is the present crown of the landslide, and thus the landward extent of current movement (Moore et al., 2010);

- $\quad$ An upper landslide section (C) of a number of rotational landslide blocks of Upper Greensand and Chalk, which account for the presence of shore-parallel benches separated by steep scarp slopes;

- $\quad$ A low-lying depression landward of the compound slide (D), containing an infilling of Chalk debris.

- $\quad$ A lower landslide section of compound slides (E), comprising a shore-parallel linear ridge of displaced Chalk debris about $500 \mathrm{~m}$ wide and $20 \mathrm{~m}$ high;

The relationship between building damage and the geomorphology (Fig 3) indicates that the most severe damage in historical times has occurred within the Lowtherville Graben. This damage indicates on-going landslide displacement and has continued at the graben to the present day (Fig 3, P1). 
Observations of ground deformation generally follow periods of prolonged ranfall (e.g. the wet winter of 2012) resulting in the need for continued maintenance of the Newport Road (Anon, 2013). The damage further shows the lateral shear between two distinct landslide units, which extends seaward from the graben in upper Ventnor to the west of Bath Road (Fig 3, P2). Less severe damage is concentrated along the edges of separate landslide blocks in upper Ventnor and along Ventnor Park Road in Lower Ventnor (Fig 3).

\subsection{LANDSLIDE GROUND MODEL}

A ground model for the Ventnor landslide, developed by Halcrow (2006) (Fig 4), shows a deep-seated landslide. Borehole data confirmed that movement occurs on a clearly-defined basal shear surface at a depth of about $95 \mathrm{~m}$ below ground level and extends offshore. The basal shear surface is located at the base of the Gault Clay formation in Upper Ventnor, and between the contact of the displaced Gault Clay and Sandrock Unit 2d further downslope. Groundwater monitoring indicates that the sand-rich horizons of the Sandrock (notably units $2 \mathrm{a}, 2 \mathrm{c}$ and 2e), the Upper Greensand, the Lower Chalk and the chalk debris are more permeable (and water bearing) than the clay-rich units of the Gault Clay and Sandrock. This gives rise to four distinct saturated zones, GWT1-4 (Moore et al. 2010). Three of the groundwater tables are specifically significant to the landslide (Fig 4):

- GWT1 is a perched aquifer within the Upper Greensand, which is recharged by rainfall percolating through the porous caprocks of the Chalk Downs. It is vertically separated from the lower aquifers by relatively impermeable Gault Clay;

- GWT2 is a confined aquifer within the Carstone and Sandrock 2c, sandwiched between the Gault Clay the underlying Sandrock unit 2d ;

- GWT3 is a confined aquifer within Sandrock unit 2c, sandwiched between Sandrock clay units $2 \mathrm{~b}$ and $2 \mathrm{~d}$. GWT3 discharges to the sea about $20 \mathrm{~m}$ below sea level.

On a regional scale these confined aquifers drain out of the Chalk Downs towards the Undercliff, following the regional dip of the strata to the SSE, and as a consequence artesian pressures can develop.

Displacements measured over the last 26 years (Table 1) show that the majority of sites across the landslide have been moving at rates in the range 0 to $6 \mathrm{~mm} / \mathrm{yr}$ (Moore et al. 2007a). In all studies, the greatest rates of movement have been recorded in the area of the Lowtherville Graben, which is consistent with the distribution of damage across the town (Fig 3). Whilst this suggests that the crown of the landslide is subject to greater current displacements than is the lower landslide block, inclinometer data (Table 2) indicates that movement in Ventnor Park (BH4I) is greater. This provides evidence that landslide movement occurs throughout the complex although with higher local surface strain rates in the headscarp area. 


\section{MONITORING APPROACH}

As noted above, Ventnor has been subject to the collection of ground-movement and groundwater data from various locations across the landslide (Table 3), using techniques that include automated standpipe piezometers and crackmeters; differential GPS surveys; and manually measured standpipe piezometers and inclinometers (Fig 5).

Vibrating wire crackmeter records are available from 1992 to 2002. Two crackmeters were installed within the Lowtherville Graben and additional crackmeters were installed at Bath Road and the Winter Gardens in Lower Ventnor (Fig 5). The instruments were installed using a standard methodology (Dunnicliff, 1993). Each instrument was buried within shallow excavations and anchored to the ground either side of the crack at both the transducer and connecting-rod ends of the crackmeter The sensors were connected to an automated data logger which collected measurements of crack extension at threehourly intervals, providing a record of horizontal crack opening, including periods of accelerating and decelerating opening.

Vibrating-wire settlement cells were installed at the site in 1992 to measure relative vertical deformation. The two settlement cells were installed within the Lowtherville Graben and a further cell was installed at Bath Road in Lower Ventnor (Fig 5). Pressure transducers were buried within shallow pits alongside a liquid reservoir. As the ground settled the pressure exerted in the liquid column was converted to a measurement of settlement and automatically recorded by a data-logger.

The movement records at the Lowtherville Graben have been analysed in relation to groundwater monitoring data collected from vibrating-wire piezometers installed at a range of depths at the Winter Gardens in Lower Ventnor 1995 (Fig 5). The piezometers recorded groundwater level between 1995 and 2002 at three-hourly intervals.

The equipment yielded mostly high-quality data, although equipment reliability resulted in some data gaps. This study focuses on the period May 1998 to October 2002 inclusive, when the most reliable data were collected.

The ground movement and groundwater data have been analysed in relation the rainfall data collected at the Ventnor Park weather station (Figs 5 and 6). The weather station recorded daily rainfall, temperature, evapo-transpiration and wind conditions, which allowed the analysis of total daily, total monthly and effective rainfall over the $\sim 4.5$ year study period.

\subsection{PATTERNS OF LANDSLIDE BEHAVIOUR AT VENTNOR}

Crack-opening data are available for 1626 days from 07 May 1998 to 19 October 2002, during which the crack at crackmeter $\mathrm{C} 1$ opened $34.36 \mathrm{~mm}$ (Fig 6), giving an average opening rate of $0.021 \mathrm{~mm} / \mathrm{day}$ (7.71 mm/year). The temporal pattern of opening was variable, and can be divided into three phases. 
- Phase 1: From the start of monitoring on 07 May 1998 until 30 November 2000, the crack opened at an approximately constant rate of $0.021 \pm 0.016 \mathrm{~mm} /$ day $(\sim 7.71 \mathrm{~mm} /$ year$)$.

- Phase 2: From about 1 December 2000, the crack-opening rate increased substantially to an average of $0.094 \pm 0.027 \mathrm{~mm} /$ day $(\sim 34.38 \mathrm{~mm} /$ year $)$. This rate was sustained until about 25 March 2001, when the rate of opening reduced.

- Phase 3: from 26 March 2001 until the end of the monitoring period on 19 October 2002, a slow rate of opening was observed that varied about an average of $0.0092 \pm 0.083 \mathrm{~mm} / \mathrm{day}$ $(\sim 3.35 \mathrm{~mm} /$ year $)$.

Almost identical patterns of opening are seen at both crackmeters which were located $38 \mathrm{~m}$ apart from each other. A similar temporal pattern is also seen in settlement cell SC1 although the other settlement cell (SC2) has a notably different pattern (Fig 6). In the latter case, the Phase 2 period is not observed; instead the graben settlement appears to have occurred in a series of irregularly-spaced steps. However, there is much noise in this dataset, and the inference may not be correct.

Fig 7 depicts histograms of the daily opening rates for the three phases for crackmeter $\mathrm{C} 1$. These suggest that statistically the three phases are distinctly different. The faster movement phase (Phase 2; Fig 7b) shows a distribution with a slightly negative skew (-0.12) and a negative kurtosis (-0.31). Phase 1 has a positive skew (0.329) and a neutral kurtosis (-0.080). Phase 3 has a negative skew (0.44) and a strong positive kurtosis (15.65). It is perhaps surprising that Phases 1 and 3 are so distinctly different, perhaps suggesting that after a faster opening event (Phase 2) it takes some time for stress changes in the landslide to settle and allow a long-term slow opening pattern to re-establish.

Much less difference between the three periods is seen in the settlement cell data (Fig 8), despite the greater magnitudes of change, suggesting that settlement cells provide a less effective monitoring tool than the crackmeters. This is likely to be a reflection of the nature of movement of the graben. The crackmeters more directly measure the primary movement mechanism - extension of the landslide due to spatially faster movement of the blocks on the lower part of the slope. The settlement cells may measure a response to this movement - settlement of the graben block - which is likely to be less responsive and more complex than the landslide extension measured by the crackmeters.

An accelerated crack-opening phase was recognised as occurring when the mean daily opening rate, calculated from a five day running mean, exceeded a threshold rate of $0.05 \mathrm{~mm} / \mathrm{day}$. The period of faster opening (Phase 2) (Fig 9a), in which the majority of measured opening occurred, was a response to a period of unusually high precipitation (Fig 9b). The period of wet weather started with a rainfall of $4.6 \mathrm{~mm}$ on 12 September 2000. This generated a pore-pressure response that started on about 19 September 2000 (a lag of seven days) although the rapid increase in pore pressure did not start until 11 October 2001, suggesting a lag of about 29 days (Fig 9c). The rate of crack opening on the landslide started to increase as an immediate response to the elevated pore pressure, although the movement threshold for accelerated crack opening (0.05 mm/day) was not reached until 1 December 2001. 
The accelerating part of the faster opening phase lasted about 30 days (Fig 9c).

Porewater pressure peaked on 19 December 2000, whilst the peak opening rate for this initial phase of faster movement occurred shortly before, on about 16 December 2000. The initial acceleration part of the Phase 2 event is highly non-linear with respect to porewater pressure although most of the increases in movement occur at generally higher pore pressures.

Through the first four months of 2001, the porewater pressure remained high, although it fluctuated considerably in response to precipitation (Figs 9b and c). In February 2001 slightly lower precipitation resulted in a reduction in pore pressure and the crack-opening rate reduced. However, a renewed spell of precipitation in March led to an increase in porewater pressures once more, and the rate of opening of the cracks increased. The highest opening rate in the period was recorded on 8 March 2001 as porewater pressures also peaked in this latter stage of the enhanced movement phase on 6 March 2001; thereafter, the opening rate rapidly reduced as porewater pressure fell. Fig 7a suggests that this is an almost instant response to the end of the spell of increased precipitation, which was marked by a 15.6 mm rainfall event on 6 March 2001. The crack-opening rate declined below the threshold value on $0.05 \mathrm{~mm}$ /day on 26 April 2001 (49 days after the peak), and to background levels on about 26 May 2001. At this time the porewater pressure was still above its background level (Fig 9c).

Over the same period, a similar analysis for the settlement cells does not distinguish the phase of increased deformation rate (Fig 9d). This is partly because the data are noisy. However, even when the data are smoothed, a similar period of increased deformation rate is not identifiable.

Whilst the relationship between deformation and groundwater level appears comparatively simple, the Ventnor landslide demonstrates a more complicated relationship between deformation and precipitation (Fig 10) The highest daily precipitations were in September and early October 2000 but the landslide did not respond then. The period from October to late December 2000 had more frequent daily precipitation, but peak daily totals were smaller. It is this relatively prolonged period of precipitation input that appears to have driven a rapid increase in groundwater level and thus the accelerated movement event

It is inferred from Fig 10 that porewater pressure controls the movement of the landslide, especially when porewater pressures increases (Fig 11a) in response to increased precipitation. The deformation initially showed only a small response, but a threshold appears to have been passed at a pore pressure of about $107 \mathrm{kPa}$, beyond which the landslide deformation increased significantly (Fig 11a). However, once pore pressures had peaked, the relationshop between deformation and pore pressure became more complicated (Fig 11b).

The patterns of deformation in Phases 1 and 3 are also complicated. Fig 12 shows the displacement at Crackmeter 1 against time during Phase 1, together with the average deformation during this phase and 
the local pore pressure. Interpretation of the data is confounded by data gaps due to equipment failure, January 1999, after which the deformation rate increased and remained at an elevated level for about 14 months. This long period of increased deformation rate appears to have been initiated by high pore pressures in January 1999, but deformation rate remained high even as porewater pressure reduced. However, in March 2001, the faster deformation slowed as porewater pressure fell.

The deformation recorded by the settlement cells show a different pattern for the same period (Fig 13). Vertical deformation appears to have varied seasonally, with higher rates in winter and spring (December to April) than in summer and autumn (May to November). Porewater pressure does not follow this pattern.

\section{DISCUSSION}

Monitoring of the surface deformation pattern on the Ventnor landslide has provided insights into the ongoing evolution of this landslide complex. A continuous very slow background deformation is observed, which suggest the landslide complex is subject to continuous ground movement at 5-10 mm per year. The background pattern is complicated and does not appear to correlate with local porewater pressure. This is similar to the observations on the large Utiku landslide in New Zealand by Massey et al. (2013). The explanation for this is unclear - it could be that the landslide responds to porewater trends over the whole of the mass, which may not be captured by the monitoring data reported here, or to some other factor (e.g. porewater chemistry; Moore and Brunsden, 1996) that has not been investigated. An alternative explanation may be that the landslide displays 'stick-slip' behaviour (e.g. Petley et al., 2005; Allison and Brunsden, 1990). The exact causal mechanism of this movement remains to be fully understood.

A pattern of seasonal settlement and uplift is observed at settlement cells SC03, SC06 and SC11. Similar uplift and settlement cycles have been detected at other landslide sites (e.g. Zhou et al., 2010; Massey et al. 2013) and linked to drying and wetting causing changes in soil moisture and local volumetric soil shrinkage and swelling. In previous studies, these effects have been shown to occur at shallow depths around the settlement cell and therefore are not the result of landslide movement and they are not controlled by porewater pressure at depth.

A distinct period of increased deformation rate was recorded at the Lowtherville Graben, This period of faster ground deformation was controlled by increased porewater pressures and is consistent with the graded movement patterns previously observed at other landslide sites (e.g. Petley et al., 2002; 2005; Moore and Brunsden, 1994; Allison and Brunsden, 1990), and in laboratory studies on material deformation ( $\mathrm{Ng}$ and Petley, 2009). During the main period of increase in porewater pressure, there was a notable but non-linear rise in deformation rate, especially above a threshold of $107 \mathrm{kPa}$. However, once faster deformation was occurring, the relationship with porewater pressure was not simple. A reason for this is unclear, but we suggest that the local deformation may respond primarily 
to porewater pressures and movement across the entire landslide mass rather than that occurring locally. The consequence of this is that the correlation with measured short term precipitation is poor.

During slowing of the deformation, there is a quick response as porewater pressures reduce. Ground deformation then returns to a slow background deformation as porewater pressures drop below 107 $\mathrm{kPa}$. Below this threshold, changes in porewater pressure are not reflected in changes in deformation rate, suggesting that the movement mechanism is different. A similar change in deformation mechanism is observed in other landslides (Alison and Brunsden 1990; Massey et al. 2013) and in laboratory studies (Ng and Petley 2009).

The movement pattern in the graben reveals marked differences in the timing and amount of vertical and horizontal deformation in the landslide. Specifically, the response of the graben initially is extension, presumably associated with movement along the basal landslide shear surface, which generates mostly horizontal deformation. The relationship of the basal sliding movement to porewater pressure is strong. In response to extension the settlement cells measure the vertical deformation of graben. This movement response is consistent with graben behaviour at the rear of a deep-seated landslide where the dominant movement is translational (Massey et al. 2013). In addition it demonstrates that an understanding of the types of landslide process operating at a site is essential to ensure effective slope monitoring systems are installed to measure ground movement behaviour.

The landslide movement behaviour at Ventnor indicates that the deformation is not brittle, primarily because movement is occurring as slow slip on a well-developed basal shear surface along which large strain has developed (Petley et al. 2005a). There is no evidence of movement patterns that would indicate a progressively developing failure against the criteria identified in Petley et al. (2005b). Thus, catastrophic failure, as observed in many first-time landslides in brittle materials (Petley et al. 2002), is unlikely without a profound change in groundwater conditions or in the stress state (through, for example, the removal of a toe block).

The relationship between deformation rate and groundwater level indicates that slow creep of the landslide is likely to continue, with periods of faster deformation when porewater pressures exceed the $107 \mathrm{kPa}$ threshold. Such movement is likely to continue to be damaging to property and infrastructure in Ventnor.

\section{CONCLUSIONS}

The Ventnor Landslide complex is currently in a state of marginal instability and as a consequence is subject to continued, very slow deformation. The landslide shows two key patterns of movement slow continual deformation and more rapid deformation when a porewater pressure threshold is exceeded. The main movement mechanism is sliding on a low-angle basal shear surface at >90 metres depth; the landslide mass overlying this is a series of back-tilted blocks and highly deformed grabens. 
Vertical deformation within the Lowtherville Graben is more complicated than its horizontal deformation. Faster vertical deformation occurs following extension of the graben. In addition, the vertical deformation shows a seasonal component that may be associated with winter wetting and summer drying. We suggest that in the case of Ventnor at least, settlement cells are not the optimum approach for analysing long-term deformation patterns; this may apply to other similar landslides.

Under current conditions the likelihood of a rapid, catastrophic failure is considered to be low. Future ground deformation is therefore likely to occur faster during periods when porewater pressures at the landslide shear surface are elevated above the $107 \mathrm{kPa}$ critical threshold. In such instances movement is likely to occur as periods of faster ground deformation which, whilst being damaging for the town, are unlikely to develop into large, rapid ground displacements without large changes to the landslide hydrogeology or stress state.

\section{ACKNOWLEDGEMENTS}

The results presented in this paper are the product of collaborative $\mathrm{PhD}$ research between Halcrow, a CH2M-HILL Company, and the International Landslide Centre at the Department of Geography, University of Durham. The research was funded, in part, through the Halcrow Award Scheme. The authors acknowledge the work and support of the Isle of Wight Council which has invested significantly in the continued monitoring and maintenance of the Ventnor Landslide Management Strategy, to which they have allowed access. The authors would further like to thank colleagues at Halcrow and the valuable contributions made by former colleagues and Consultants at Geomorphological Services Limited and High Point Rendel who were involved in the initial development and implementation of the Undercliff Landslide Management Strategy in the early 1990's. This manuscript has greatly improved following review comment from Russel Van Dissen and Dr Mauri McSaveney. Carey's time to prepare the manuscript was provided by GNS Science in New Zealand, whilst Petley was funded by the Earthquakes without Frontiers grant from NERC / ESRC, grant number: NE/J01995X/1. 


\section{REFERENCES}

Allison, R., and Brunsden, D. 1990. Some mudslide movement patterns. Earth Surface Processes and Landforms, 15: 297-311.

Anonymous. 2013. http://onthewight.com/2013/03/08/ground-movement-damage-on-ventnor-roads-tobe-tackled/ Accessed on 16/10/2014.

Casagli, N., Filippo, C., Del Ventisette., and Luzi, G. (2010). Monitoring, prediction, and early warning using ground based radar interferometry, Landslides, 7: 291-301.

Chandler, M.P. 1984. The Coastal landslides forming the Undercliff of the Isle of Wight. Ph. D. Thesis (unpublished), Imperial College, University of London.

Corominas, J., Moya, J., Ledesma, A., Lloret, A., and Gili,, J.A. (2009). Prediction of ground displacements and velocities from groundwater level changes at the Vallcebre landslide (Eastern Pyrenees, Spain). Landslides, 2(2), 83-96.

Dunnicliff, J. 1993. Geotechnical Instrumentation for Monitoring Field Performance. Wiley, Chichester, $608 \mathrm{pp}$.

Du, J., Yin, K., and Lacasse, S. 2013. Displacement prediction in colluvial landslides, Three Gorges Reservoir, China. Landslides 10(2), 203-218.

Fukuzono, T. 1990. Recent studies on the time prediction of slope failures. Landslide News, 4: 9-12.

Geomorphological Services Limited, 1987. Review of Research into Landsliding in Great Britain. Series A: Regional review of landsliding - regional atlases of country maps at 1:25,000 scale, regional reports. Report to the Department of the Environment.

Halcrow. 2006. Ventnor Undercliff, Isle of Wight Coastal Instability Risk: Interpretative Report and Quantitative Risk Analysis. Technical Report to the Isle of Wight Council.

Hutchinson, J.N. 1987. Some coastal landslides of the southern Isle of Wight. In: K.E. Barber (Editor), Wessex and the Isle of Wight. Field Guide. Quaternary research Association: Cambridge, pp. 123135.

Hutchinson, J.N., Bromhead, E.N., and Chandler, M.P. 1991a. Investigations of the landslides at St Catherines Point, Isle of Wight. In: R.J. Chandler (Editor), International Conference on Slope Stability Engineering-Development and Applications, London: Thomas Telford. pp. 213-218.

Hutchinson, J.N., and Bromhead, E.N. 2002. Keynote Paper: Isle of Wight landslides. In: R.G McInnes and J Jakeways (Editors), Instability Planning and Management: Seeking Sustainable Solutions to Ground Movement Problems, Proceedings of International Conference, Ventnor. Thomas Telford: London, pp. 3-70.

Lee, E.M., and Moore, R. 1991. Coastal Landslip Potential Assessment: Isle of Wight Undercliff, Ventnor, Technical Report, Department of the Environment.

Massey, C., Petley, D.N. and McSaveney, M. 2013. Patterns of movement in reactivated landslides. Engineering Geology, 159, 1-19.

McInnes R.G. 2000. Managing ground instability in urban areas: a guide to best practice. IW Centre for the Coastal Environment.

Moore, R., and Brunsden, D. 1996. A physio-mechanism of seasonal mudsliding. Geotechnique. Vol XLVI (2), 259-278.

Moore, R. Lee, E.M. and Clark, A.R. 1995. The Undercliff of the Isle of Wight: a review of ground behaviour. Cross Publishing: London.

Moore, R., Carey, J.M., McInnes, R. G. and Houghton, J.E.M. 2007a. Climate Change, so what? Implicactions for ground movement and landslide event frequency in the Ventnor Undercliff, Isle of Wight. In: R.J McInnes, J Jakeways, H Fairbank and E Mathie (Editors), Proceedings of the International Conference Landslides and Climate Change, Ventnor Isle of Wight. Taylor \& Francis, London. pp. 335-344

Moore, R., Turner, M.D., Palmer, M.J., and Carey, J.M. 2007b. The Ventnor Undercliff: Landslide model, mechanisms and causes, and the implications of climate change induced ground behaviour risk. In: R. J McInnes., J Jakeways., H Fairbank, and E Mathie (Editors), Proceedings of the 
International Conference Landslides and Climate Change, Ventnor Isle of Wight. Taylor \& Francis, London. pp. 365-375.

Moore, R., Carey, J.M., and McIness, R.G. 2010. Landslide behavior and climate change: predictable consequences for the Ventnor Undercliff, Isle of Wight. Quarterly Journal of Engineering Geology and Hydrogeology, 43, 447-460.

Ng, K-Y., and Petley, D.N. 2009. A process approach towards landslide risk management in Hong Kong. Quarterly Journal of Engineering Geology and Hydrogeology 42 (4) 487-498.

Palmer, M.J., Moore, R., and McInnes, R. 2007. Reactivation of an ancient landslip, Bonchurch: event history, causes, mechanisms, climate change and landslip potential. International Conference on Landslides and Climate Change - Challenge and Solution, Ventnor, Isle of Wight

Pankow, K.L, Moore, J.R., Hale, J.M, Koper, K.D, Kubacki, T., Whidden, K.W., and McCarter, M.K. 2014. Massive landslide at Utah copper mine generates wealth of geophysical data. GSA Today, 24 (1), 4-9.

Petley, D.N. 2012. Remote sensing techniques and landslides. In: Clague, J. and Stead, D. Landslides Types, Mechanisms and Modeling. Cambridge University Press, pp. 159-71.

Petley, D.N., Bulmer, M.H.K., and Murphy, W., 2002. Patterns of movement in rotational and translational landslides. Geology, 30 (8): 719-722.

Petley, D.N., Mantovani, F., Bulmer, M.H.K., and Zannoni, F. 2005a. The interpretation of landslide monitoring data for movement forecasting. Geomorphology, 66 (1-4), 133-147.

Petley, D.N., Higuchi, T., Petley, D.J., Bulmer, M.H. and Carey. J., 2005b. The development of progressive landslide failure in cohesive materials. Geology, 33(3): 201-204.

Saito, M. 1965. Forecasting the time and occurrence of a slope failure. Proceedings of the 6th International Conference on Soil Mechanics and Foundation Engineering. 2. pp. 537-541.

Saito, M. 1980. Semi-logarithmic representation for forecasting slope failure. Proceedings of the International Symposium on Landslides, 1, 321-324.

Yin, Y.,Zheng, W., Lui Y., Zang, J., and Li, X. 2010. Integration of GPS with InSAR to monitoring of the Jiaju landslide in Sichuan, China, Landslides, 7 (3), 359-365.

Zhou, Y.D., Tham, L.G., Kwong, A.K.L., and Tang, X.W. 2010. Mechanism of drying induced rebound movements in a soil slope in Sai Kung, Hong Kong. Engineering Geology, 116, 86-94. 


\section{FIGURE CAPTIONS}

Figure 1. (a),(b) and (c) Site location of the Ventor landslide in relation to The Undercliff on the south coast of the Isle of Wight (LiDAR data courtesy of Channel Coastal Observatory).

Figure 2. Map of the Ventnor landslide and ground investigation locations (Aerial Photograph courtesy of Channel Coastal Observatory).

Figure 3. The spatial distribution of damage in relation to landslide geomorphology, mapped by Geomorphological Service Limited (1991) and modified from Moore et al., (2010), (P1) the Lowetherville Graben photographed in 2005, (P2) damage recorded at Bath Road during ground movement in 1960 (reproduced from Moore et al., 2007a).

Figure 4. The Ventnor landslide ground model (based on Halcrow 2006).

Figure 5. Location of site monitoring instruments.

Figure 6. Horizontal and vertical displacement measured between 07 May 1998 and 19 October 2002 at crackmeters and settlement cells in the Lowtherville Graben.

Figure 7. Histograms of ground movement phases recorded at Crackmeter 1 in the Lowtherville Graben (a) Phase 1: between 07 May 1998 and 30 November 2000 (b) Phase 2: between 1 December 2000 and 25 March 2001 (c) Phase 3: between 26 March 2001 and 19 October 2002.

Figure 8. Histograms of ground movement phases recorded at Settlement cell 4 in the Lowtherville Graben (a) Phase 1: between 07 May 1998 and 30 November 2000 (b) Phase 2: between 1 December 2000 and 25 March 2001 (c) Phase 3: between 26 March 2001 and 19 October 2002.

Figure 9. Ground movement behaviour during the enhanced movement phase (Phase 2) in the Lowtherville Graben (a) Cumulative vertical and horizontal displacement (b) Cumulative precipitation (c) Horizontal displacement rate in relation to porewater pressure (d) Vertical displacement rate in relation to porewater pressure.

Figure 10. Relationship between during horizontal displacement rate and daily rainfall during the enhanced movement phase (Phase 2) in the Lowtherville Graben.

Figure 11. Relationship between ground movement rate and porewater pressure during the enhanced movement phase (Phase 2) in the Lowtherville Graben (a) acceleration phase (b) deceleration phase.

Figure 12. Relationship between patterns of horizontal ground movement during Phase 1, recorded at Crackmeter 1 in the Lowtherville Graben, and porewater pressure.

Figure 13. Relationship between patterns of vertical ground movement during Phase 1, recorded at Settlement Cell 4 in the Lowtherville Graben, and porewater pressure.

\section{TABLE CAPTIONS}

Table 1. Ventnor historical ground movement records (Moore et al. 2007a). 
Table 2. Summary of inclinometer data 2002 to 2008.

1

Table 3. Summary of landslide monitoring instruments, Ventnor Town. 
Click here to download Table: 14_06_Carey JM Tables.pdf

\begin{tabular}{ccc}
\hline Location & Monitoring period & Movement rate (mm/yr) \\
\hline Newport Road & $1982-1983^{*}$ & 19.7 to 39 \\
Newport Road & 1988 & 28 \\
Newport Road & $1995-2009$ & 6.4 (crack extension) \\
& & 33.2 (settlement) \\
Lowtherville Graben & $1982-1983$ & 26.9 to 29.9 \\
Lower Gill's Cliff Road & $1982-1983$ & 8 to 16.5 \\
Ocean View Road & $1982-1983$ & 6 \\
Bath Road & $1982-1983$ & 0 \\
Bath Road & $1988^{* *}$ & 0 to 2 \\
Bath Road & $1995-2009^{* * *}$ & -0.06 (crack closure) \\
& & 22 (settlement) \\
Esplanade & $1949-1988$ & 20 (heave) \\
\hline Note ${ }^{*}$ after Chandler (1984) ${ }^{* *}$ after Woodruff (1989) ${ }^{* * * C o u n c i l ~ r e c o r d s ~}$
\end{tabular}

Table 1.

\begin{tabular}{ccc}
\hline & \multicolumn{2}{c}{ Measured displacement (mm) } \\
DATE & BH2 (Upper Ventnor) & BH4I (Lower Ventnor) \\
\cline { 2 - 3 } & Depth & Depth \\
& $93 \mathrm{~m} \mathrm{bgl}$ & $76 \mathrm{~m} \mathrm{bgl}$ \\
\hline $2002-2003$ & 15 & - \\
$2003-2004$ & 9 & - \\
$2004-2005$ & 9 & - \\
$2005-2006$ & 7 & 9 \\
$2006-2007$ & 0 & 14 \\
$2007-2008$ & 8 & 9 \\
Total & 48 & $\mathbf{3 2}$ \\
Annual Rate (2002-2008) & 8.0 & - \\
Annual Rate (2005-2008) & 5.0 & 10.7 \\
\hline
\end{tabular}

Table 2. 


\begin{tabular}{lccc}
\hline Installation & $\begin{array}{c}\text { No. of } \\
\text { instruments }\end{array}$ & Locations & Monitoring period \\
\hline Vibrating wire crackmeter & 3 & Bath Road & $1995-2004$ \\
& & Newport Road Bath & $1995-2002$ \\
Vibrating wire settlement cell & 4 & Noad & $1995-2004$ \\
& & Winter Gardens & $1995-2004$ \\
Vibrating wire piezometer & 2 & Winter Gardens & $1992-2004$ \\
Manual inclinometers & 2 & BH2 & $2002-2008$ \\
& & BH4l & $2005-2008$ \\
Annual movement marker & 57 & & \\
Survey & & Ventnor Town & \\
\hline
\end{tabular}

Table 3. 

Figure 1

Click here to download high resolution image

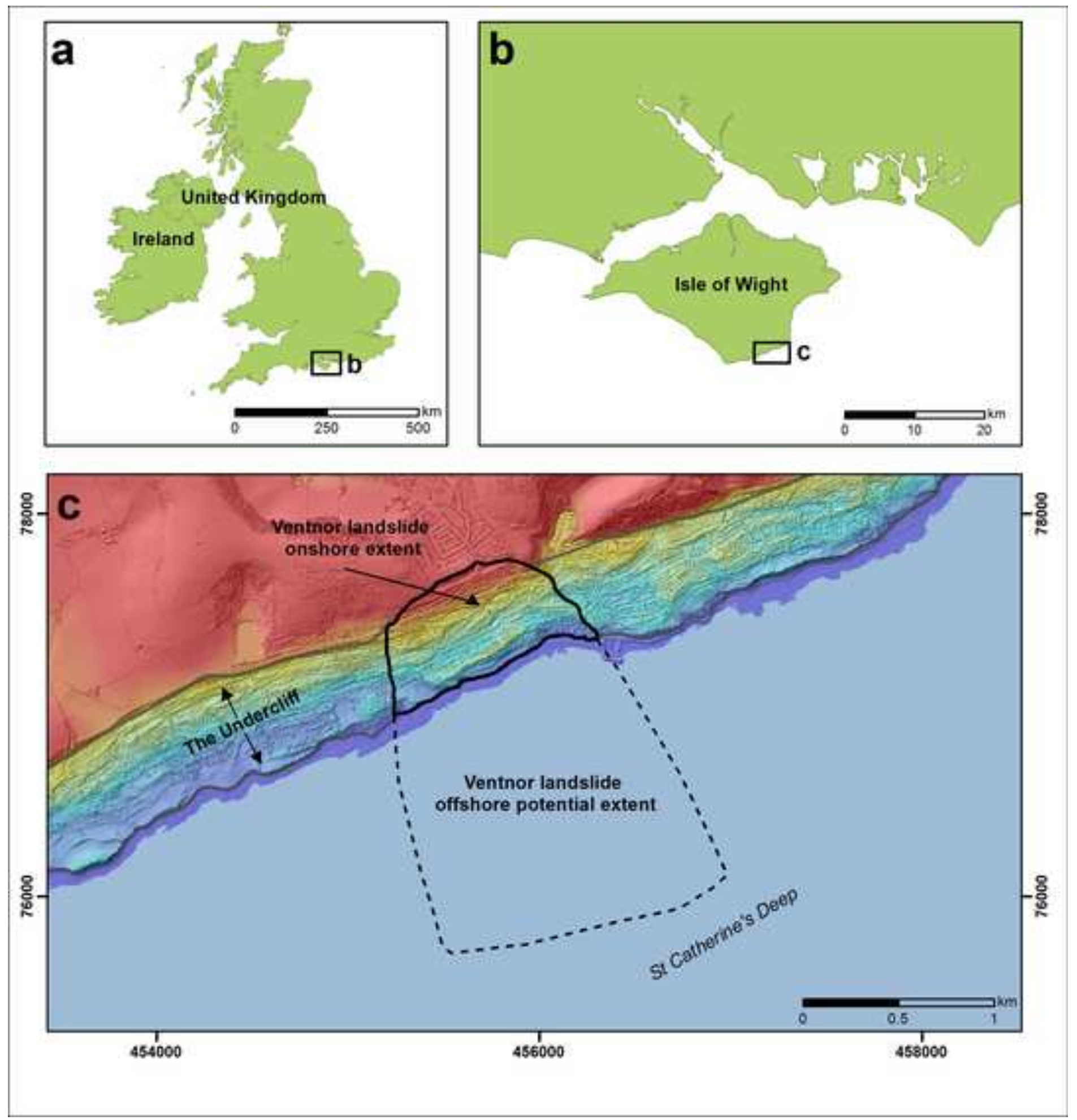


Click here to download high resolution image

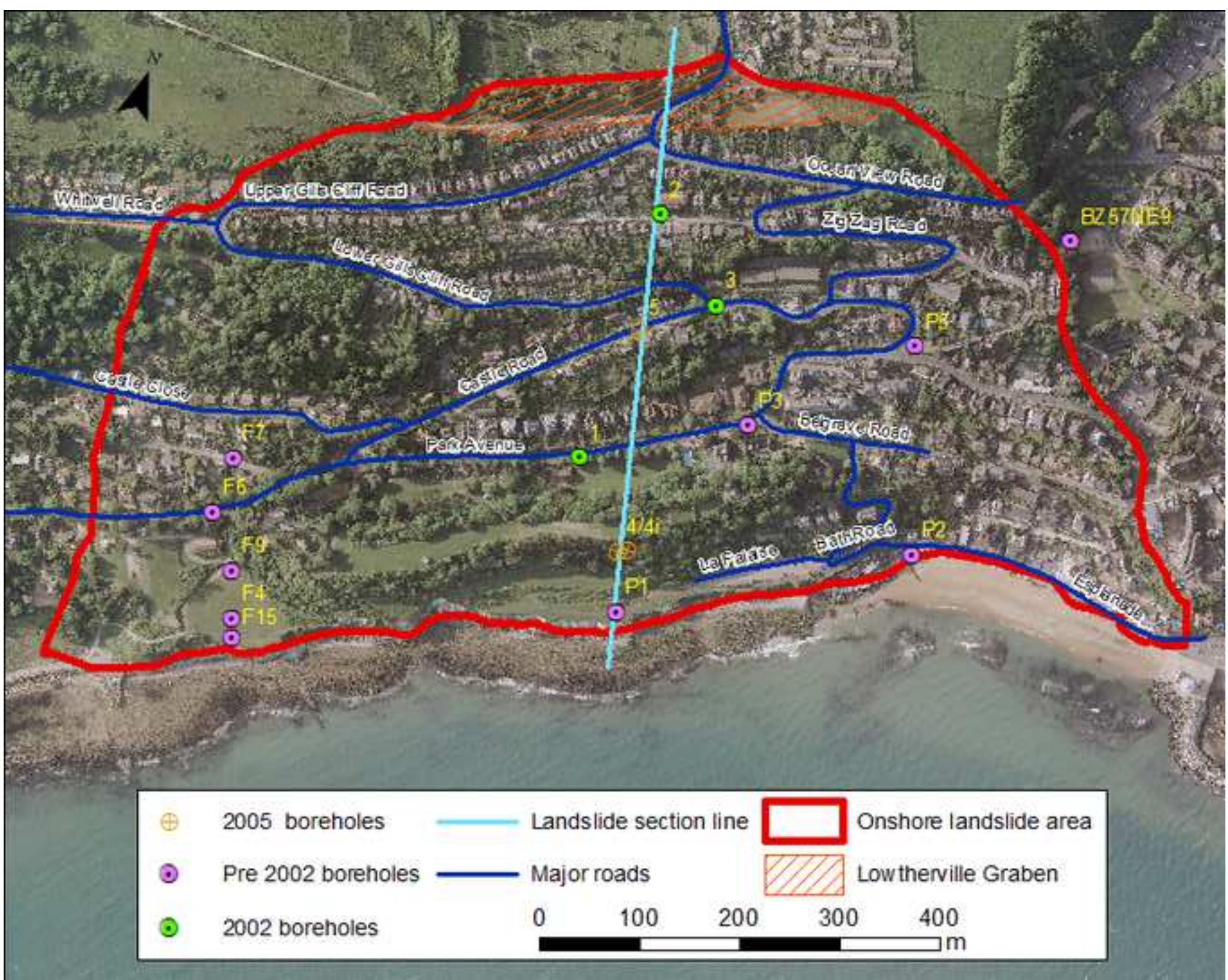




\section{Figure 3}

Click here to download high resolution image
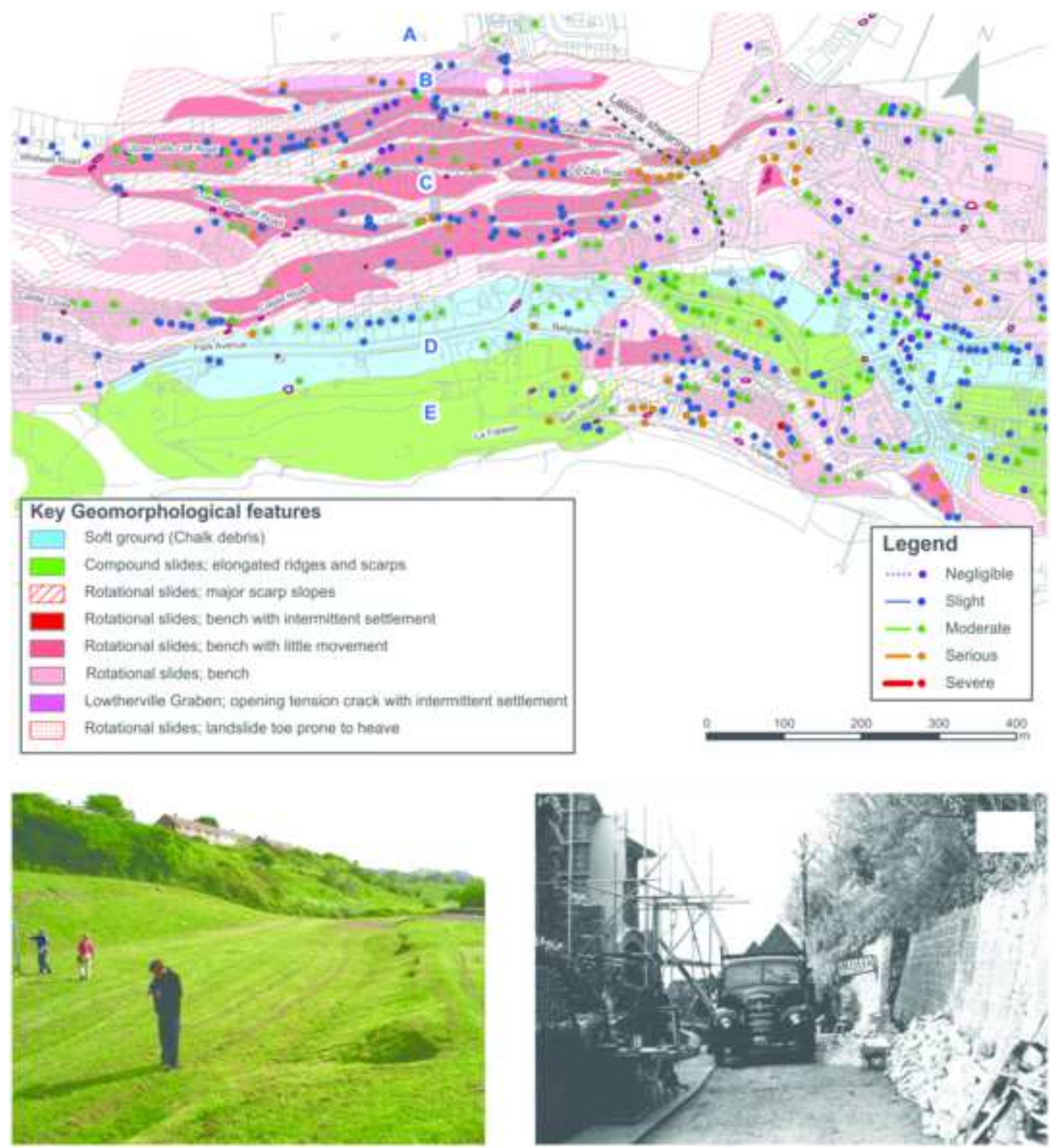
Upper landslide section

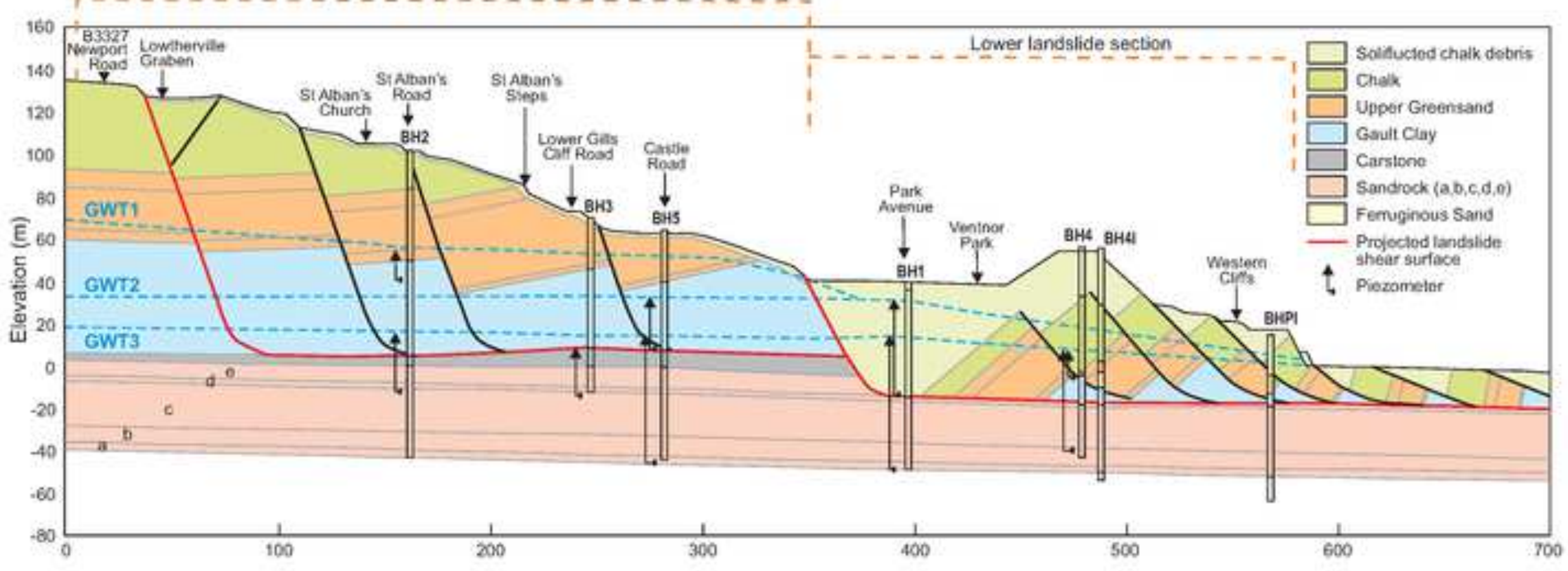

Figure 4 
Click here to download high resolution image

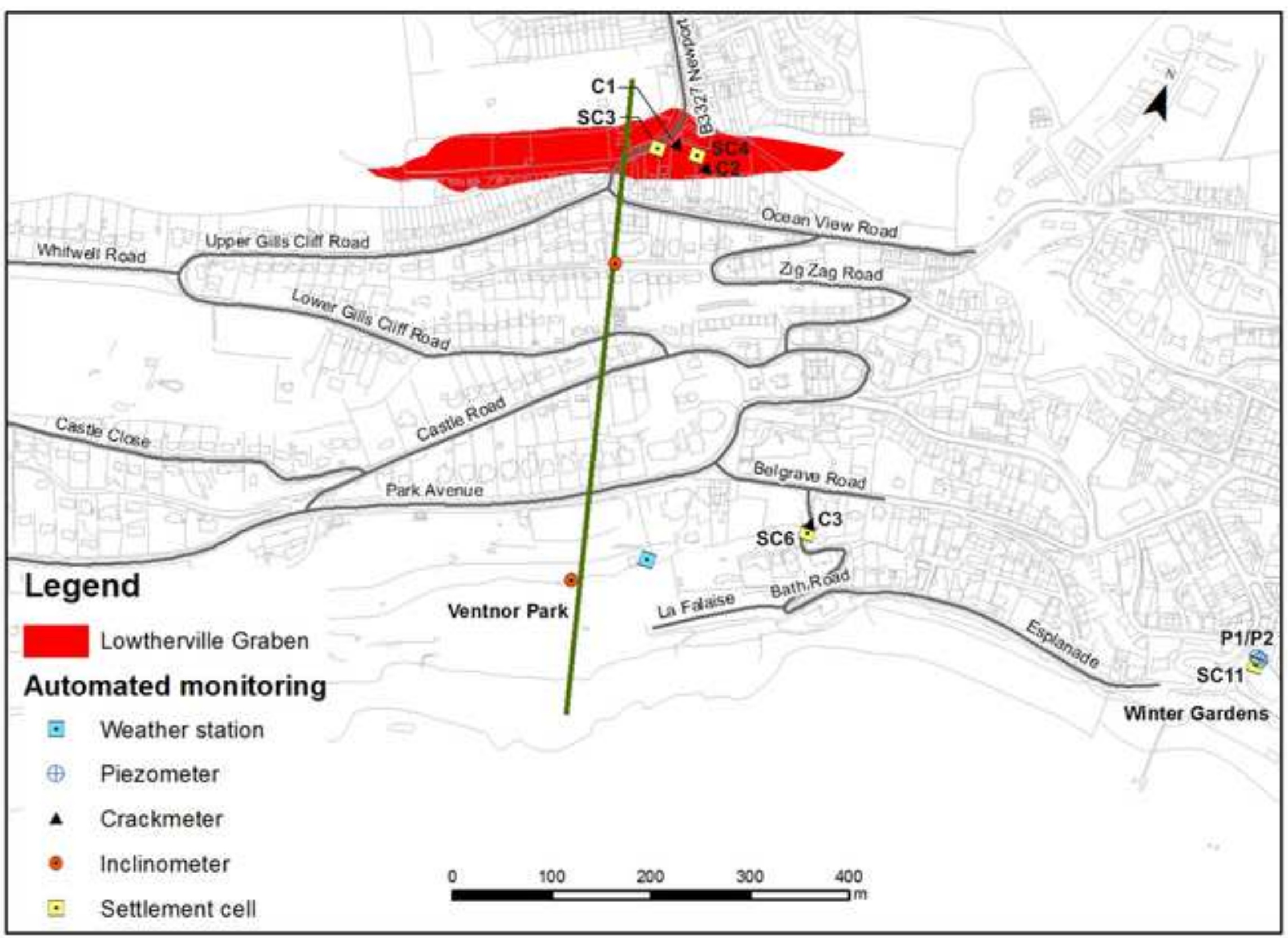

Figure 5 
Figure 6

Click here to download high resolution image

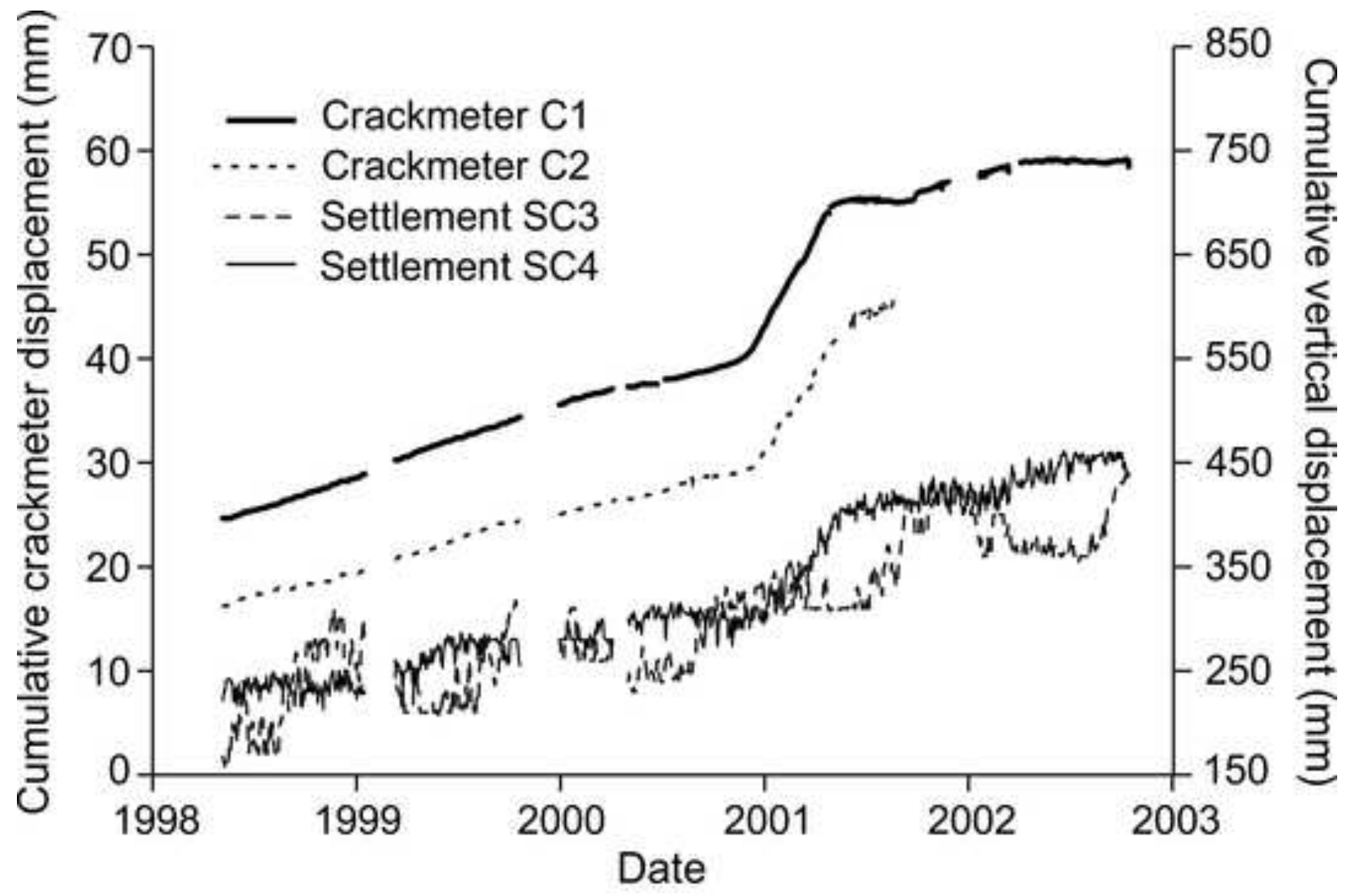

Figure 6 
Click here to download high resolution image
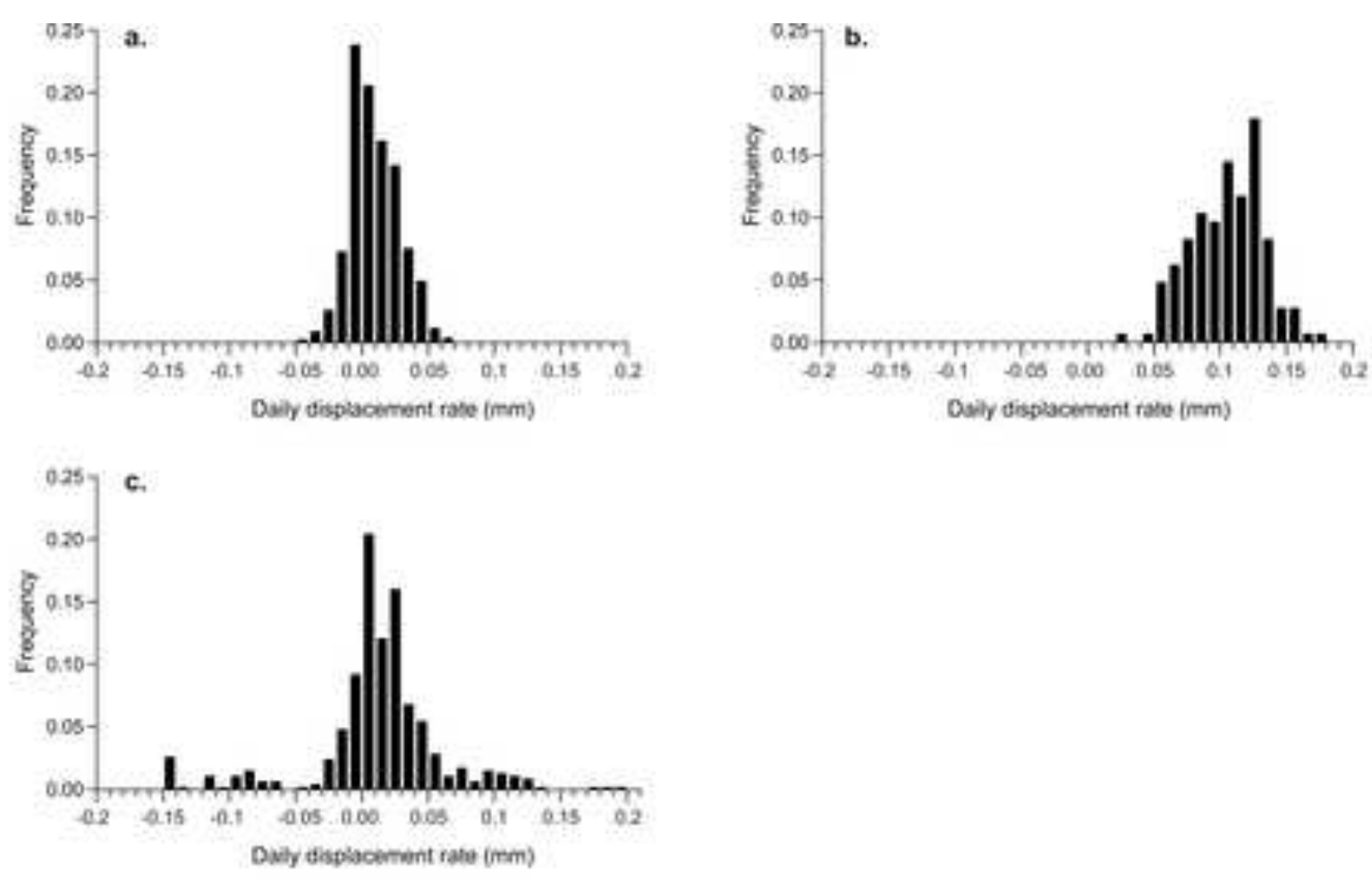

Figure 7 

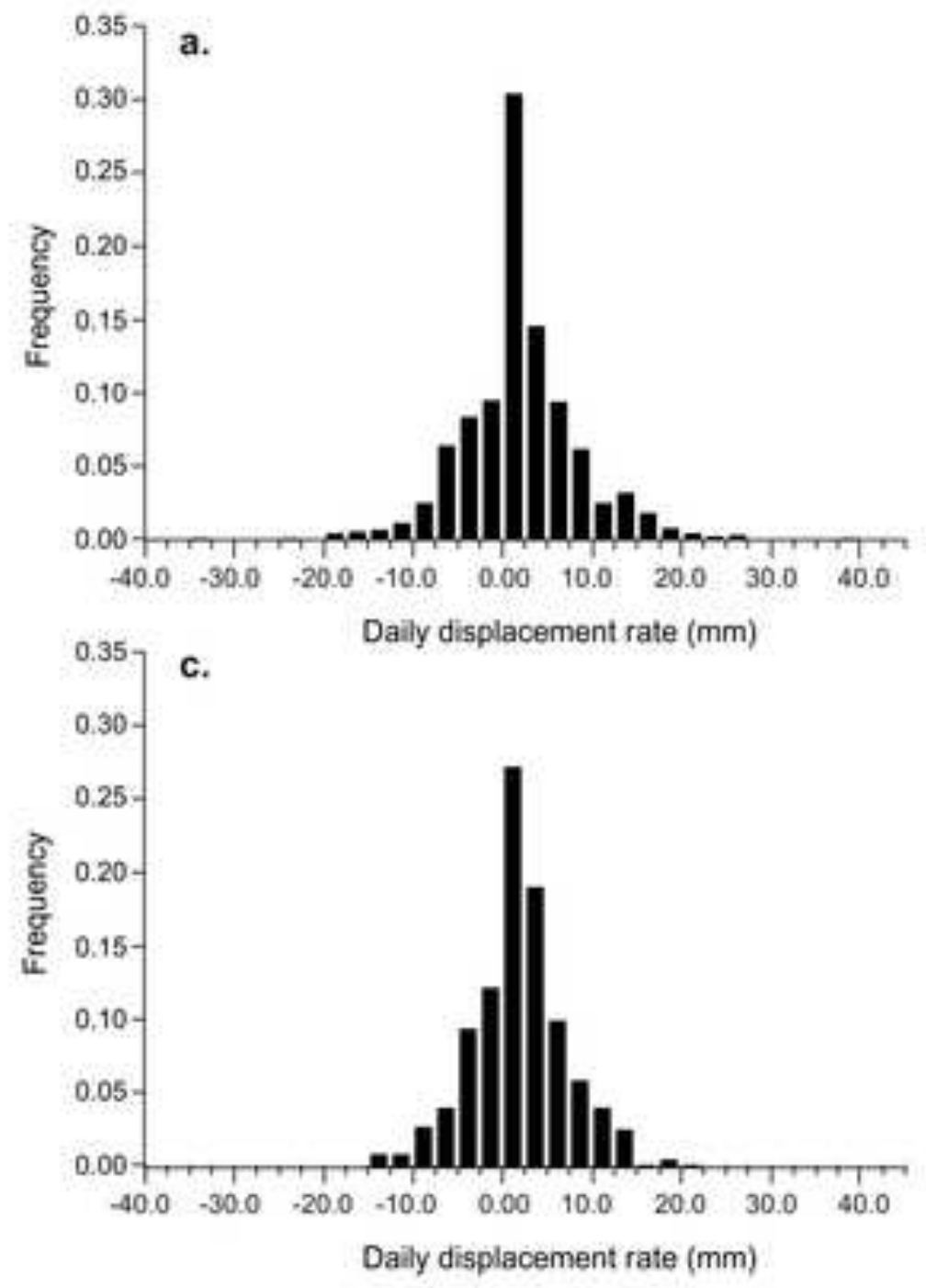

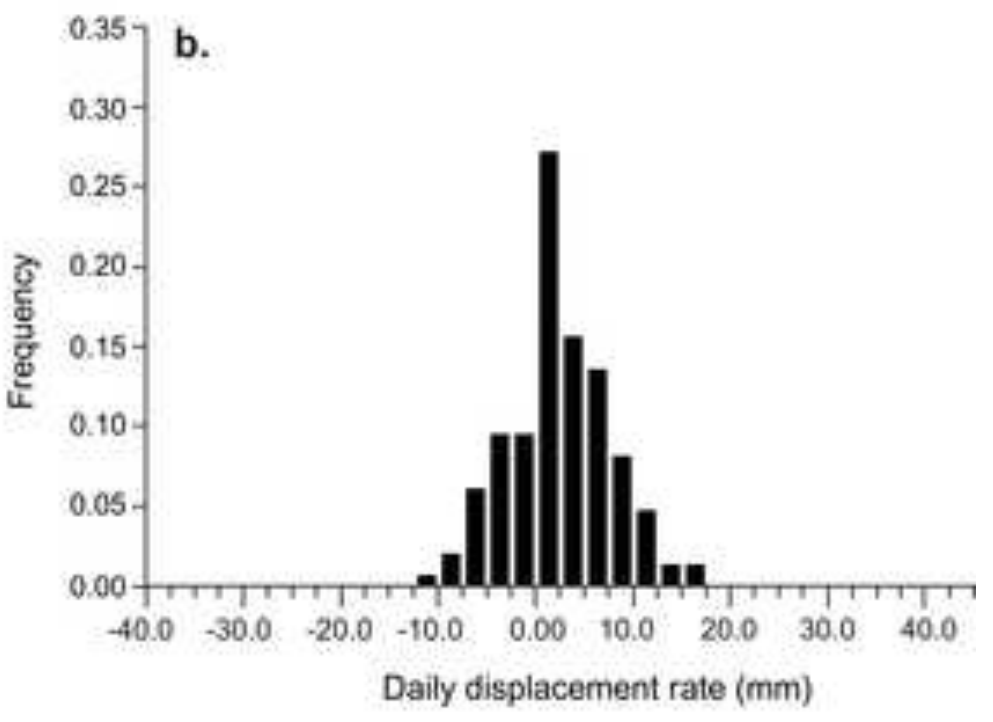

Figure 8 

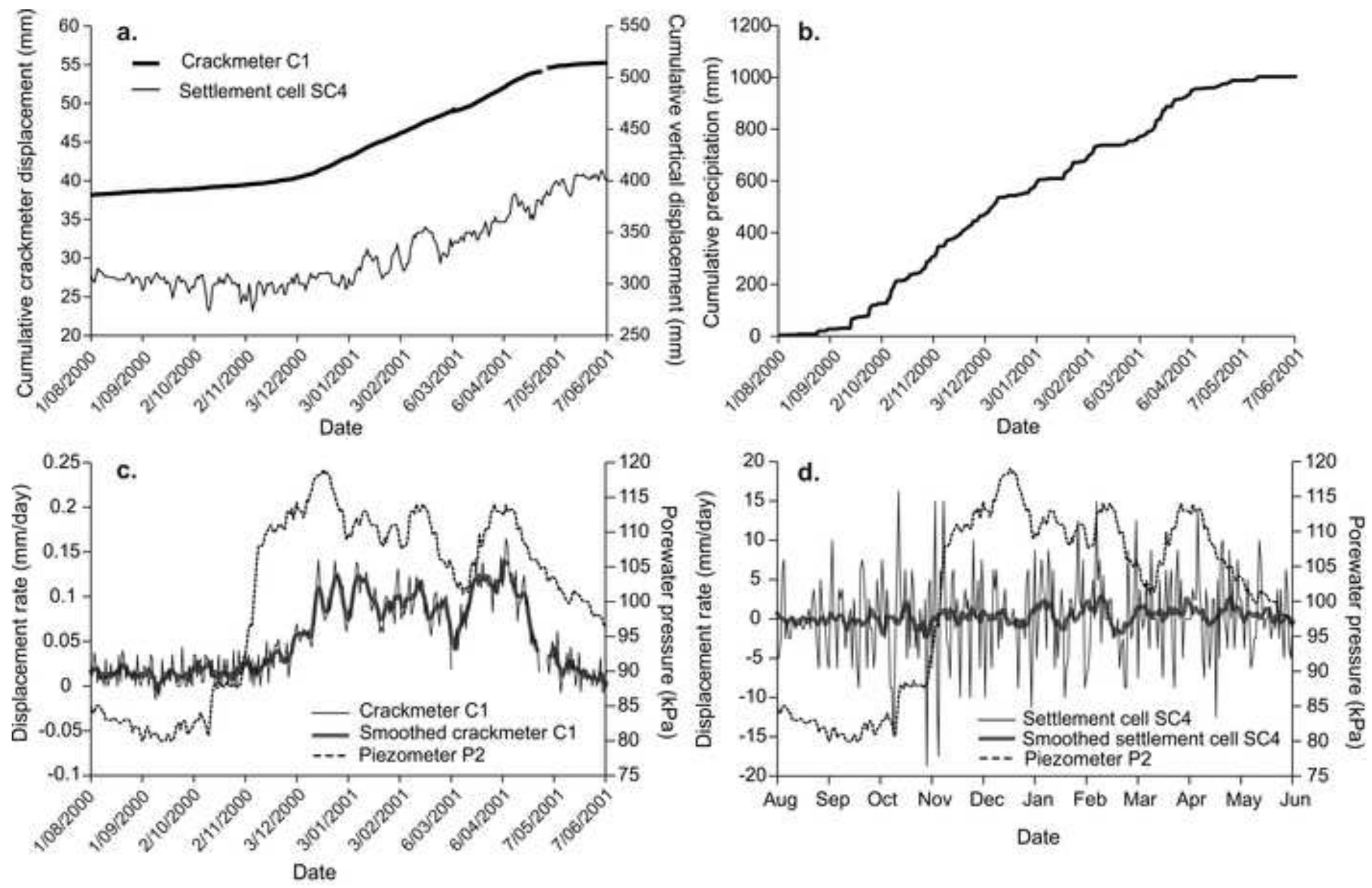

Figure 9 


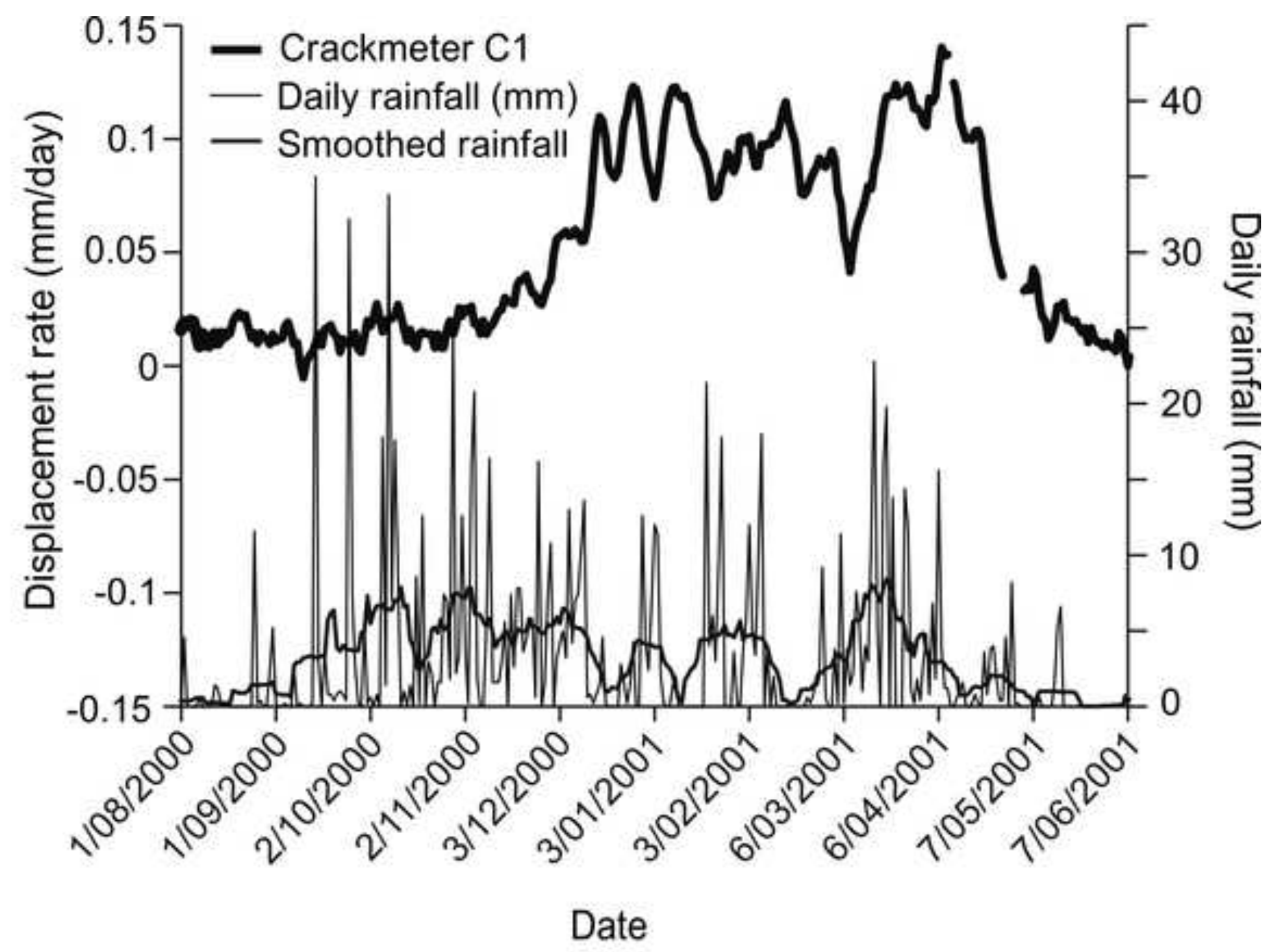

Figure 10 

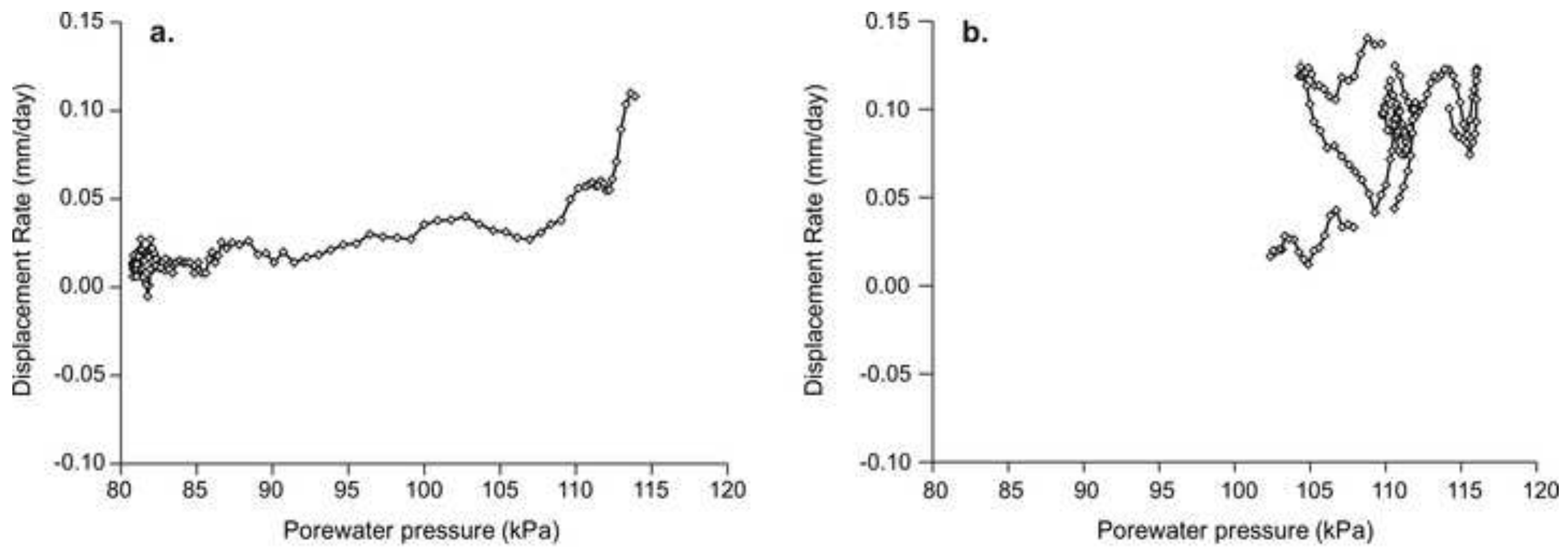

Figure 11 


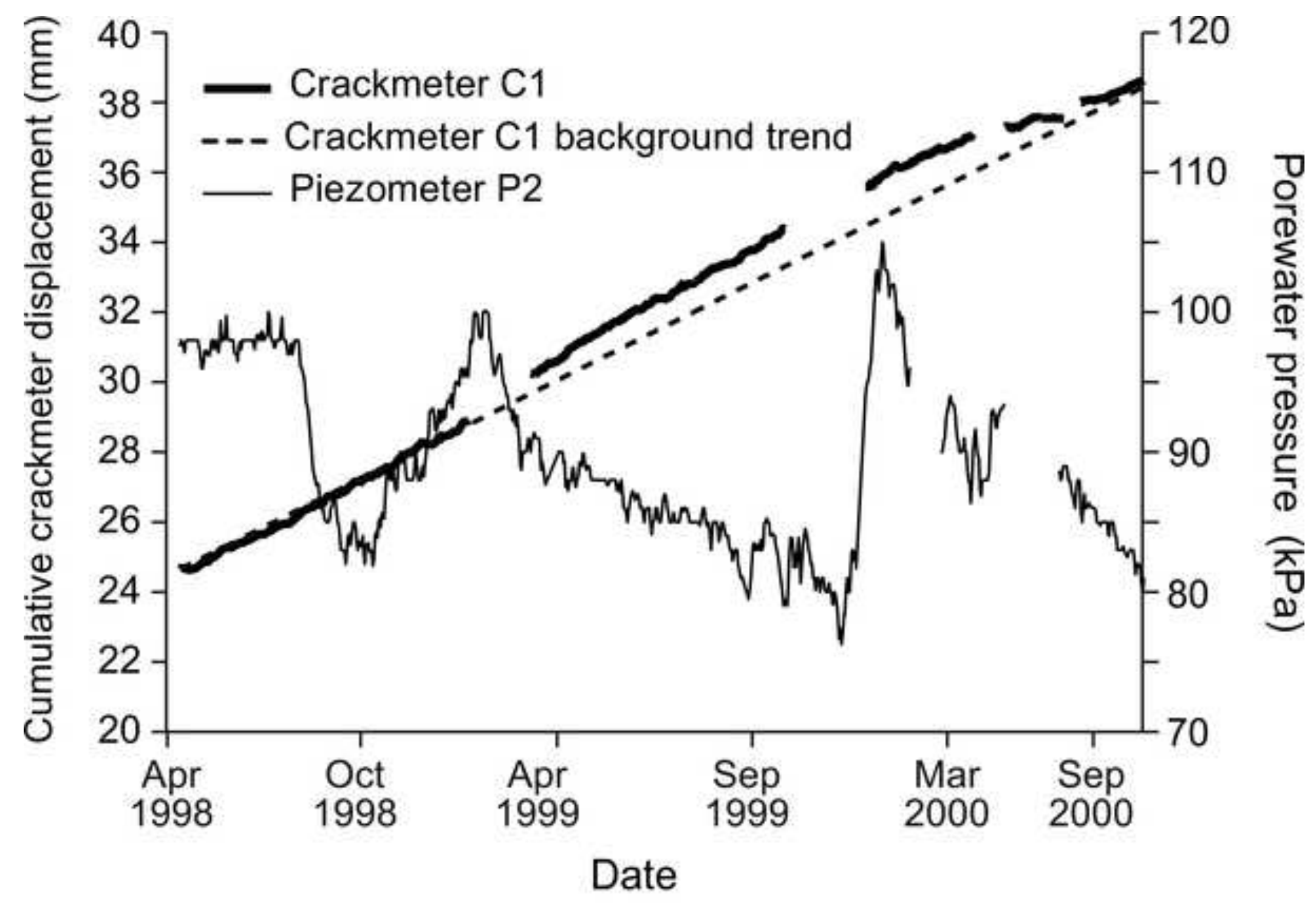

Figure 12 


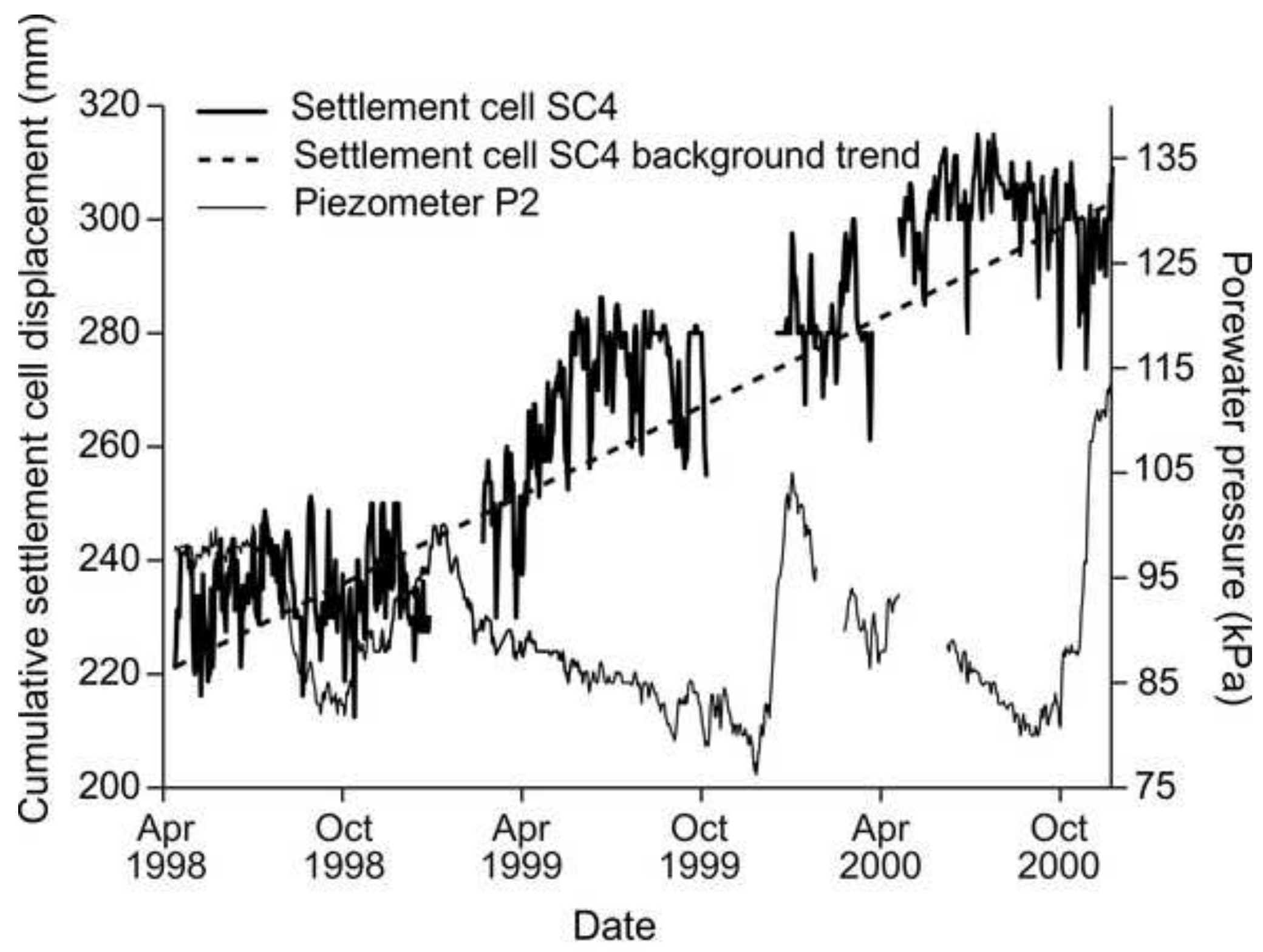

Figure 13 